\title{
Safeguarding the National Airspace of Indonesia under the Framework of International Air Law
}

\author{
Harry Purwanto ${ }^{1}$ \\ ${ }^{1}$ Faculty of Law, Universitas Gadjah Mada, Indonesia \\ hari.purwanto@ugm.ac.id
}

\begin{abstract}
Introduction to the Problem: The vast territory of Indonesia requires careful thought in realizing an effective defense system to maintain its territorial integrity and the safety of the nation. To ensure the effectiveness of the country's broad defense system requires great strength, high mobility, and early detection capability. The development of Indonesia's defense force should not merely be oriented towards the land territory, but it must also be optimized towards the country's sea and air forces. Purpose/Objective Study: This study examines the airspace protection system implemented by Indonesia to protect the security of the country from threats.

Methodology: The research design is exploratory as this paper aspires to explore the basis of air defense identification zone.

Findings: The Indonesian Government has taken legal measures by regulating restricted airspace, air defense identification zones, as well as identifying types of violations committed by foreign aircraft. Both national and international laws allow Indonesia to establish air defense identification zones.
\end{abstract}

Paper Type: General Review

Keywords: Air Defense Identification Zone; Airspace; Law; Indonesia

\section{Introduction}

The territory of a country generally consists of the land area, sea area, and airspace above it. As also stated by Priyatna Abdurasyid (Setiani, 2018) and Hugh Kindred (Brunnée et al., 2014), that: "the territory of the country consists of three dimensions, namely, land, sea and air. Airspace is an upward projection of the earth's surface in the form of land and sea or waters. State sovereignty over airspace is influenced by State sovereignty over land and sea areas. Based on the United Nations Convention on the Law of the Sea or the United Nations 1982, the state has sovereignty over marine areas in the form of inland seas, territorial seas, and archipelagic waters. So that airspace under the sovereignty of a State includes airspace over land, over inland waters, over the territorial sea, and over archipelagic waters, for an archipelagic State (Lestari, 2017).

The state's sovereignty over airspace has been accepted by member states of the international community, both through international treaties (the 1944 Chicago Convention on International Civil Aviation and the 1982 United Nations Convention on the Law of the Seas) and through customary international law (Lestari, 2015). The 
control and utilization of airspace are generally carried out from the surface of the earth because in reality and from the aspect of government management, it is from the surface area of the earth that the government of a country can carry out and controls overall government activities including activities in the airspace (Rachmawati \& Dewi, 2020). As stated by Meilinger, that: "whoever controls the air, generally control the surface", control of airspace from the earth's surface is important (Purwanto \& Mangku, 2016). However, presently the international community has not managed to agree on the vertical limit air space above the earth's surface area that is under the sovereignty of states. Meanwhile, the horizontal limit of state sovereignty over its air space adopts the boundaries of the earth's surface that is in the sovereignty of the state concerned.

Following the horizontal boundary pattern of the airspace, it is understood that Indonesia's national airspace is vast, which includes air space above its land, the airspace above its internal waters, the airspace above its territorial waters, and airspace above its archipelagic waters. The land area of Indonesia is 1,922,570 square kilometers, and the area of Indonesian waters is 3,257,483 square kilometers (Ariani et al., 2017). Indonesia's national airspace is at one of the air intersections in the world, which obviously has its own positive and negative impact. The positive impact, among others, is that the airspace can be utilized as a source of foreign exchange for Indonesia, given the busy traffics of civilian flights passing through its national airspace. As for the negative impact, among others, is the dense flight intensity itself which requires Indonesia to be more vigilant in maintaining its security in the air, in addition to the frequent violations of the national airspace. Airspace is even deemed vulnerable when viewed from the aspect of national defense and security. Apart from being able to be used to attack other countries, it can also be used for the advantage of espionage in peacetime (Sefriani, 2015). Therefore, the Indonesian government must always protect its national airspace.

As a juridical implementation of state sovereignty in airspace, Article 5 jo, Article 1 paragraph (2) of Law No. 1 of 2009 on Aviation affirms that: "The Unitary State of the Republic of Indonesia has full and exclusive sovereignty over the airspace of the Republic of Indonesia". What is meant by airspace is the area of air sovereignty over the land and waters of Indonesia. As a consequence, Indonesia has the authority and responsibility for regulating airspace for the interests of aviation, national economy, national defense and security, socio-culture, and the air environment in order to protect citizens and their assets (Article 6 of Law Number 1 of 2009).

Safeguarding the national airspace, besides being intended to safeguard the defense and security of the State, is also to anticipate any violations committed by foreign aircraft entering the national airspace without permission. In order to ensure the broader effectiveness of the national defense system, it requires great strength, high mobility, early detection capabilities, and a strong and definite legal foundation. The implementation of State defense and security, besides based on Law Number 3 of 
2002 on State Defense, is also based on Law No. 1 of 2009 and Indonesian Government Regulation No. 4 of 2018 on Security of the Airspace of the Republic of Indonesia. Law No. 1 of 2009 and Government Regulation No. 4 of 2018 stipulate the formation of an air defense identification zone.

\section{Methodology}

The research design is exploratory as this paper aspires to explore the basis of air defense identification zone. Sources of this study are secondary data sources consisting of primary legal materials, secondary legal materials and tertiary legal materials. Through this writing, an assessment is made upon the possibility of the Government of Indonesia in establishing an air defense identification zone in the framework of securing the airspace area.

\section{Results and Discussion}

\section{Indonesian National Airspace}

Airspace, like sea territory, brings benefits to the interests of the humans (the state), namely as a means of transportation and communication, a unifying medium, national resources, and the media for national defense and security. Therefore, it is very necessary to have a set of legal provisions, both at the national and international levels, to regulate state activities in the airspace. The existence of various legal provisions is also intended to prevent and resolve conflicts that may arise as a result of the use of air space in various interests by states, both for national and international airspaces, to achieve and maintain order in the society as the main objective and the primary of all laws.

In relation to State sovereignty over the territory, the 1982 United Nations Convention on the Law of the Sea (UNCLOS) identifies that the state has sovereignty over sea areas within the limits of internal waters, territorial seas, and archipelagic waters (Geraldi, 2017). As for the airspace, the state has sovereignty over the airspace above the land and the waters that are under the sovereignty of the state concerned. UNCLOS also stipulates the existence of sovereign rights of the State over parts of the sea area, which are the contiguous zones, exclusive economic zone (EEZ), and the continental shelf. It is different from the 1944 Chicago Convention on International Civil Aviation (ICAO Convention), which only states that the State has sovereignty over airspace above the territory under the sovereignty of the State concerned (Prabandari, 2019).

Indonesia is one of the countries that has ratified both the UNCLOS and the ICAO Convention. Hence Indonesia has sovereignty over its land areas, internal waters, territorial seas, archipelagic waters, as well as complete and exclusive sovereignty over the airspace above them. Thus, the territory of Indonesia consists of three dimensions, namely the dimensions of land, sea, and air. This means that Indonesia has sovereignty over land, sea, and air areas, of course within the boundaries justified 


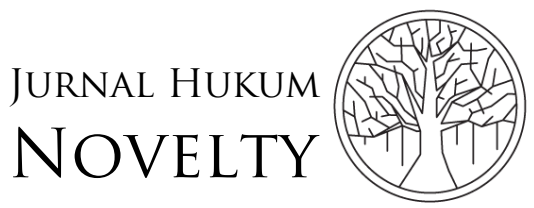

Volume 12, Issue 02, 2021, pp. 191-203

P-ISSN: $1412-6834$

E-ISSN: 2550-0090

in international law. However, based on the ICAO Convention, there is no recognition of the State's sovereign rights over air space.

In the context of Indonesian national law, sovereignty over territory adopts the terminology that designates the type of the territory, such as the term Sea Territory or Airspace territory, which both means the sea area or the airspace that is under Indonesian sovereignty (Article 1 paragraph 1 of Government Regulation No. 4 of 2018 on Security of the Airspace of the Republic of Indonesia). That being said, the Indonesian Airspace refers to the certain area bearing air sovereignty over the Indonesian land and waters. Whereas for the sovereign rights with the term jurisdiction area, Article 1 paragraph 3 of Law No. 43 of 2008 generally states that, "Jurisdiction Area is an area outside the State Territory consisting of the Exclusive Economic Zone, Continental Shelf, and Additional Zone where the state has rights". These sovereign rights and certain other authorities are as stipulated in statutory regulations and international law. Meanwhile, jurisdictional airspace is specifically defined as airspace outside the country's territory consisting of the Exclusive Economic Zone, Continental Shelf, and Additional Zone where the state has sovereign rights and certain other authorities in accordance with the provisions of laws and regulations and international law (Article 1 paragraph 2 Government Regulation No.4 of 2018 concerning Security of the Airspace of the Republic of Indonesia).

Thus, in addition to the sovereignty of the state over its airspace is recognized and regulated in Law No.1 of 2009 on Aviation, Law Number 43 of 2008 also recognizes and regulates the sovereign rights of Indonesia over its airspace. In international law, various international treaties or conventions do not regulate the sovereign rights of states over air space. However, through their respective Government Regulations, there is an attempt by States to exercise their jurisdiction in airspace which is not under the authority of the State concerned, with the consideration of Territorial Security or State defense and security (Dirwan, 2011). In this case, the State may take certain steps against aircraft that fly near the airspace of the State (not yet within the sovereign territory of the State), for the sake of safeguarding the airspace or defense and security of the State concerned.

\section{The Importance of National Defence and Security}

In the context of exercising State sovereignty over the airspace of the Republic of Indonesia, the Indonesian Government has the authority and responsibility for regulating airspace for economic interests, aviation safety, and State Defence and Security (Article 5, 6 of Law No. 1 of 2009 on Aviation). Managing the territory, especially the airspace for a sovereign country, should be in the interests and the welfare of the people as well as the defense and security of the country.

Especially with regard to the defense and security aspects, the airspace of the Republic of Indonesia plays a role in protecting the Indonesian citizens and their assets. The airspace of the Republic of Indonesia is used to withstand air attacks from 
outside. The vast territory of Indonesia requires careful thought in realizing an effective defense system to maintain territorial integrity and the safety of the nation. In order to ensure the effectiveness of the country's broad defense system, it requires great strength, high mobility, and early detection capability. The development of Indonesia's defense force must not only be oriented towards the land territory but it must also be optimized towards the sea and air power.

Air defense is part of the national defense. In the context of the Republic of Indonesia, National Defence is an effort to defend the sovereignty of the State, the territorial integrity of the Republic of Indonesia, and the safety of the entire nation from threats and disturbances to the integrity of the nation and the State (Article 1 of Law Number 3 of 2002 of State Defence). The management of State defense is carried out in the form of activities at the strategic and policy level, which include planning, implementation, supervision, and control of State defense (Sa'diyah \& Vinata, 2016). A major component in defense of the Republic of Indonesia is the Indonesian National Army (TNI) which consists of the (land) Army (AD), the Navy (AL), and the Air Force (AU) (Jazuli, 2016).

\section{Security of the National Airspace}

Today, the framework of safeguarding Indonesia's national airspace is equipped with the issuance of Government Regulation Number 4 of 2018 on the Security of the Airspace of the Republic of Indonesia. The Government Regulation emphasizes the context of implementing state sovereignty over the Airspace of the Unitary State of the Republic of Indonesia, and the Government exercised the authority and responsibility for regulating airspace for the interests of aviation, national economy, national defense and security, socio-culture, and the air environment (Article 4 of Government Regulation No. 4 of 2018). Indonesian air space is used for the benefit of civil aviation and defense, the implementation of which is carried out jointly in civilmilitary cooperation between the ministries that carry out government affairs in the field of transportation and the ministry that administers government affairs in the defense sector. This collaboration aims to ensure Aviation Safety by giving priority to TNI aircraft in carrying out sovereignty enforcement, law enforcement, military operations, and training (Yustitianingtyas et al., 2021). In order to carry out its responsibilities, the Government determines:

\section{Prohibited Air Areas}

A prohibited area is the air territory above land and/or waters with permanent and comprehensive restrictions for Aircraft. The prohibited areas include: a). the airspace above the Presidential Palace; b). the airspace above nuclear installations; and c). the airspace above certain strategic national vital objects as stipulated by the President based on the recommendation of the Minister of Defence, after obtaining considerations from the minister in charge of government affairs in the transportation sector (Article 7 paragraphs 2, 3, 4 of Government Regulation No. 4 of 2018). 


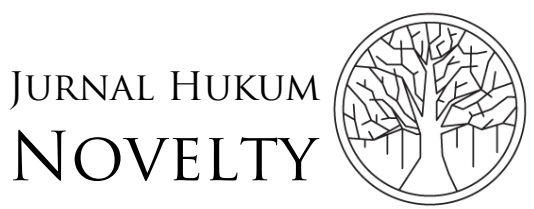

Volume 12, Issue 02, 2021, pp. 191-203

P-ISSN: 1412-6834

E-ISSN: 2550-0090

\section{Limited Air Area (Restricted Area).}

It refers to certain airspace above land and/or waters with non-permanent restrictions and can only be used for flight operations by State Aircraft (aircraft used by the TNI, POLRI, Customs, and other government agencies) (Silmiwati, 2017). Such temporary limitations can be in the form of time and altitude restrictions (Sefriani, 2015). The limited areas include: a. TNI Headquarters; b. TNI Air Base; c. military training area; d. military operation area; e. military flight training area; f. military shooting training area; g. rocket and satellite launch areas; and $h$. airspace used for flights and/or activities carried out by persons at the level of the head of state and/or heads of government (Article 8 Government Regulation No. 4 of 2018).

\section{Air defense identification zone (ADIZ)}

Certain airspace above land and/or waters designated for the purpose of identifying Aircraft for the sake of national defense and security, which is located at: a). air space in sovereign Airspace; and b). airspace in jurisdictional Airspace (Article 9 Government Regulation No. 4 of 2018).

\section{Airspace Violation}

In connection with the issuance of Government Regulation No. 4 of 2018, there are several types of violations that may be committed by foreign aircraft in the national airspace. This Government Regulation emphasizes that Foreign State Aircrafts flying to and from or through the national airspace must have diplomatic and security clearances. According to the Government Regulation, unscheduled Foreign Civil Aircrafts flying to and from or through the national airspace must have flight approval in addition to diplomatic and security clearance.

Therefore, an airplane without a license is a violation of Article 10 of Government Regulation No. 4 of 2018 and subjects to administrative sanctions in the form of a fine of not more than IDR 5,000,000,000.00 (five billion rupiahs), which is carried out by the minister who administers government affairs in the field of transportation in accordance with its authority. It is also emphasized that airplanes are prohibited from flying through the prohibited areas.

Foreign State Aircrafts in this context is defined as an Aircraft as part of a ship and/or Foreign State Aircraft flying from the country of origin (land-based aircraft), either a single flight or several aircraft in the form of formation (formation flight). Basically, by giving notification to the minister who is in charge of government affairs in the field of foreign affairs and the TNI Commander, Foreign State Aircraft can carry out cross flights through the Indonesian national airspace, through predetermined routes, for flights from one airport or airbase of other foreign countries to pass through the high seas or the Exclusive Economic Zone without disturbing Indonesia's interests in Jurisdictional Airspace (Risdiarto, 2016). In addition, Foreign State Aircraft crew who exercise the right of air traffic over Archipelagic Sea Lanes as intended are required to submit a flight plan, turn on the transponder, and 
communicate with the Aviation Traffic Guidance Service Unit, and must have a diplomatic license (diplomatic clearance) and security permit (security clearance) (see Article 19 paragraph (6) of Government Regulation No. 4 of 2018). As for Foreign Civil Aircraft, by notifying the Aviation Traffic Control Service Unit, it can fly in the Airspace over the Archipelagic Sea Channel after obtaining a flight route determined by the minister who administers the government affairs in the field of transportation and the International Civil Aviation Organization (Article 20 paragraph (2) of Government Regulation No. 4 of 2018).

In terms of the violation, when Foreign State Aircraft is flying through the route over the Archipelagic Sea Lane, it is prohibited to: (a). Perform war game manoeuvres; (b). Deviate more than 25 nautical miles on either side of the Archipelago Sea Channel axis line; and/or, (c). Fly close to the shore in less than 10 percent of the distance between the closest points on islands bordering the Archipelago Sea Channel (M. M. Lestari, 2021). Deviation from the route as intended, according to the Government Regulation, can be done after obtaining permission from the Aviation Traffic Control. Foreign State Aircraft and Foreign Civil Aircraft exercising the right of Archipelagic Sea Lane traffic and transit traffic rights in airspace that are unable to communicate and/or do not have Air Traffic Control must monitor the international radio frequency or the international emergency radio frequency at all times (Article 22 of Government Regulation No. 4 of 2018). It is also an offense when Foreign State Aircraft and Foreign Civil Aircraft fly in national Airspace and transport biological, chemical, and radioactive materials that contribute to weapons of mass destruction.

\section{The Juridical Basis for State to Establish Air Defence Identification Zones}

As mentioned above, the Indonesian Government can establish an Air Defence Identification Zone (ADIZ). In essence, there is no single international provision that explicitly regulates the determination of ADIZ by state. Through the method of interpretation and analogy, there are several legal bases in the practice of determining ADIZ that are adopted as the basis by states.

The ICAO Convention is the primary legal basis for international aviation activities, but the convention does not explicitly regulate ADIZ. Based on Article 1, the state may conduct a broad interpretation and possess the authority to determine airspace in the form of an ADIZ. States parties to the ICAO Convention affirm that the airspace under their sovereignty is basically closed territory. Therefore, states can force the foreign aircraft entering their territory to report their identity for the defense and security of the states concerned. Even though the main body of the ICAO Convention does not explicitly regulate the determination of ADIZ, but its subsidiary documents certainly do, namely Document No. 9426-AN/924 First Edition of 1984, specifically in chapter 3 on Airspace Organization, Paragraph 3.3.4 on Special Designated Airspace, which recognizes the existence of a state's ADIZ. 


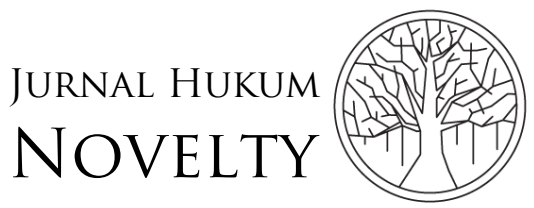

Volume 12, Issue 02, 2021, pp. 191-203

P-ISSN: 1412-6834

E-ISSN: 2550-0090

In addition, the justification for establishing ADIZ theoretically lies in the precautionary principle (Papp, 2015). Although there is no empirical or scientific evidence, nothing should prevent the State from preventing harm before it occurs to protect itself. The precautionary principle (which is also a moral and political concept) states that if an action or policy can cause severe or irreparable harm to the public, in the absence of a scientific consensus that harm is inevitable, the burden of proof falls on those who advocate taking action. The precautionary principle is most often applied in the context of the impact of human actions on the environment and human health, where the consequences of actions are impossible to predict (Garnett \& Parsons, 2017).

Then, several countries, such as America and Canada, establishing ADIZ, besides being based on Article 1 of the ICAO Convention, are also based on Cooper's Control Theory (Sudradjat \& Wahyuningsih, 2020). According to Cooper, state sovereignty in the airspace is determined by the ability of the state concerned to control the airspace above its territory (Kusumaningrum, 2017). Cooper further stated that: "...in the absence of international agreement, the territory of every state extends upward as far into space as it is physically and scientifically possible for the state to control the regions of space directly above it" (Moon, 1963).

The Air Defence Identification Zone was formed on the basis of identification needs in the air defense system for a country, where the zone generally extends from the territorial area of the country concerned to reaching the airspace above the high sea bordering the country. Basically, ADIZ is a means of supporting the national air system. Based on such thoughts, the establishment of ADIZ is based on the principle of self-defense recognized in Article 51 of the UN Charter. The right of the state to use weapons to defend itself from outside forces (other countries) is also based on customary international law (Shaw, 2003). The right to defend oneself as referred to in the UN charter is, in essence, an inherent right. The provisions in Article 51 of the UN Charter are not merely creating rights but explicitly the right to defend oneself is recognized according to the principles of international law. The right to self-defense as regulated in Article 51 of the UN Charter reads:

"Nothing in the present Charter shall impair the inherent right of individual or collective self-defense if an armed attack occurs against a Member of the United Nations until the Security Council has taken measures necessary to maintain international peace and security. Measures taken by Members in the exercise of this right of self-defense shall be immediately reported to the Security Council and shall not in any way affect the authority and responsibility of the Security Council under the present Charter to take any time such action as it deems necessary in order to maintain or restore international peace and security."

Although the editorial of the right to self-defense is implied in the article's text, its travaux preparatoires states that the right is inherent. In fact, Article 51 does not state the means that can be used to exercise the right to defend oneself. This article is often 
linked to the right to use limited armed force. Higgins, for example, argues that the UN Charter has granted limited permission for the use of armed force within the framework of the right to defend themselves both individually and collectively. The UN also considers that this act could be a mechanism to assert legal rights and achieve social and political justice. Several scholars of international law and also state practices have interpreted the right to defend oneself by expanding its meaning to self-preservation. Bowett, for example, said that Article 51 defines as the right to defend oneself, not the limitation of it. Accordingly, there is no connection between armed attacks and the right to defend oneself. States cannot simply wait for a new armed attack to be able to defend itself (Bakircioglu, 2009).

In addition, the legal basis for the establishment of ADIZ is the international practice that has become customary international law. Article 38 (1) of the Statute of the International Court of Justice states that customary international law is one of the sources of law recognized by states in general. Customary law originates from the practice of states through attitudes and actions taken on an issue. When a country takes a policy and the policy is followed by other countries and carried out repeatedly and without any protests or challenges from other parties, a habit will gradually form. By looking at the practice of States in establishing an air identification zone, where the State feels entitled to make identification in the air outside of the sovereignty of a State, moreover supported by the existence of various legal norms as a result of analogy, the State's desire to make an analogy of the existence of the sovereign rights of the State appears. In airspace based on sovereign rights in the law of the sea.

\section{Establishment of Indonesia's Air Defence Identification Zone}

Geographically, the position of Indonesia is located between two continents, namely the Asian Continent and the Australian Continent; and between the two oceans, namely the Pacific Ocean and the Indian Ocean. Such a position makes Indonesian territory, particularly the Indonesian airspace, a strategic area for the trajectory of foreign aircraft from one country/continent to another. As a consequence of Indonesia as a member of the international community, in utilizing its airspace, it must also pay attention to the interests of other countries by, of course, paying attention to legal provisions, both national and international law.

In the context of aviation, one of the efforts made by the state in controlling airspace for territorial integrity and safeguarding the state assets is by establishing an air defense identification zone or ADIZ. Therefore, talking about air defense is certainly not enough if it only talks about intercepting an aircraft, air defense radars and medium and long-range attack missiles, but it must also include ADIZ that must absolutely be owned by the Republic of Indonesia as a sovereign nation. Moreover, with the establishment of flight routes above the Indonesian Archipelagic Sea Lanes, foreign aircraft have the right to fly through flight routes above the Lanes without asking permission from Indonesia. Such conditions will certainly cause vulnerabilities if there is a lack or no control over the airspace. It creates a potential for violations 


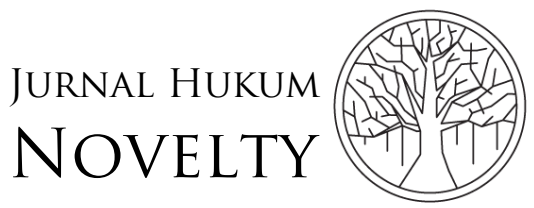

Volume 12, Issue 02, 2021, pp. 191-203

P-ISSN: 1412-6834

E-ISSN: 2550-0090

committed by foreign aircraft due to the openness of air space above the Indonesian Sea Lanes.

Determining ADIZ can be based on international law, both in the form of international agreements (Articles 1 and 2 of the ICAO Convention, Article 2 paragraph (2) and 49 (2) UNCLOS) as well as international customary law (Marsono \& D.A.R., 2018), also by using general legal theory such as the Cooper Theory as practiced by the United States and Canada. Along this line, the Pangkohanudnas Regulation No.: Perpang/04/IX/2010 stipulates ADIZ Indonesia (Indonesian Air Defense Identification Zone or IADIZ), which covers the airspace around the islands of Java, Bali, and the surrounding islands. When compared to other states in terms of determining air defense identification zones, the determination made by Indonesia is deemed insufficient in relation to State security through the airspace. The existence of the identification zone is merely within Indonesian airspace. Meanwhile, other states' zones have reached far beyond their national airspace.

In 2018, the President of the Republic of Indonesia enacted Government Regulation Number 4 of 2018 on the Security of the Airspace of the Republic of Indonesia. This Government Regulation was issued with the consideration of implementing the provisions of Article 9 of Law Number 1 of 2009 on Aviation. This Government Regulation emphasizes the context of implementing state sovereignty over the Airspace of the Unitary State of the Republic of Indonesia, and the Government exercises the authority and responsibility for regulating air space for the interests of aviation, national economy, national defense and security, socio-culture, and the air environment. The air space as referred to can be used for the benefit of civil and defense aviation, the implementation of which is carried out jointly in civil-military cooperation between the ministries that carry out government affairs in the field of transportation and the ministries that carry out government affairs in the defense sector (Article 5 of Government Regulation No.4 of 2018). The cooperation aims to ensure safe flight by giving priority to TNI aircraft in carrying out sovereignty enforcement, law enforcement, military operations, and training. In the framework of the implementation of this responsibility, the government establishes air defense identification zones, apart from restricted air areas and restricted air areas.

An air defense identification zone is a certain air space above land and/or waters that is determined to identify Aircraft for the interest of state defense and security (Article 6 paragraph (2) jo. Article 9 of Government Regulation No.4 of 2018). As mentioned in Article 1, paragraphs 1 and 2 of Government Regulation No.4 of 2018, what is meant by air space in Sovereign Airspace is the area of air sovereignty over Indonesia's land and territorial waters. Meanwhile, what is meant by airspace in Jurisdictional Airspace is airspace outside the territory of the country, which consists of the Exclusive Economic Zone, Continental Shelf, and Contiguous Zone where the state has sovereign rights and certain other authorities in accordance with the provisions of 
laws and regulations and international law. Thus, in essence, Indonesia recognizes and accepts the existence of sovereign rights in airspace as jurisdictional airspace.

However, the Government Regulation has not established the real existence of the Indonesian air defense identification zone in the airspace of the jurisdictional airspace, within which boundaries are the airspace of Indonesian jurisdiction, such as America, Canada, or the PRC, which have firmly established the existence of their air defense identification zone. Consequently, there will be difficulties in enforcing the law on foreign aircraft deemed to have violated the air defense identification zone in the jurisdictional airspace. Government Regulation No. 4 of 2018 emphasizes that foreign aircraft flying in the air defense identification zone without a diplomatic permit and a security permit will be considered as acts of deterrence and subjected to forced landing by the Indonesian Air Force.

\section{Conclusion}

Based on the description above, it can be concluded that in regards to safeguarding Indonesia's national airspace, the Indonesian Government has taken legal measures by stipulating prohibited airspace, limited airspace, as well as air defense identification zones, followed by identifying the types of violations that may be committed by foreign aircraft. Both national and international laws allow Indonesia to establish air defense identification zones. The government of Indonesia can use international law as a base to determining ADIZ, both in the form of international agreements (Articles 1 and 2 of the ICAO Convention, Article 2 paragraph (2) and 49 (2) UNCLOS), as well as international customary law, also by using general legal theory such as the Cooper Theory as practiced by the United States and Canada. As the national legal basis, Indonesia can use Law Number 3 of 2002 concerning State Defense, Law No. 1 of 2009 concerning Aviation, and Indonesian Government Regulation No. 4 of 2018 concerning Security of the Airspace of the Republic of Indonesia.

\section{Acknowledgment}

The authors would like to thank Universitas Gadjah Mada for the resources provided to conduct this research. Sincere gratitude also goes to anonymous reviewers and editors who have provided constructive feedback so that this manuscript looks worth reading and citing.

\section{Declarations}

Author contribution : Working on the entire content of the script.

Funding statement : This research is not funded under any research project.

Conflict of interest : The authors declare no conflict of interest.

Additional information : No additional information is available for this paper.

\section{References}

Ariani, Y., Soeharso, P., \& Sjarif, D. R. (2017). Genetics and Genomic Medicine in Indonesia. Molecular Genetics \& Genomic Medicine, 5(2), 103-109. 
https://doi.org/10.1002/MGG3.284

Bakircioglu, O. (2009). The Right to Self-Defence in National and International Law: The Role of the Imminence Requirement. Indiana International \& Comparative Law Review, 19(1), 1-48. https://doi.org/10.18060/17598

Brunnée, J., Kindred, H. M., Saunders, P. M., \& Currie, R. J. (2014). International Law, Chiefly as Interpreted and Applied in Canada (8th Edition). Emond Montgomery Publications.

Dirwan, A. (2011). Pengaturan Ruang Udara Diatas Alur Laut Kepulauan Indonesia (ALKI). Jurnal Ketahanan Nasional, 16(3), 1-16. https://doi.org/10.22146/JKN.12646

Garnett, K., \& Parsons, D. J. (2017). Multi-Case Review of the Application of the Precautionary Principle in European Union Law and Case Law. Risk Analysis, 37(3), 502-516. https://doi.org/10.1111/RISA.12633

Geraldi, A. R. (2017). Yuridical Analysis to the Concept of Exclusive Economic Zones and Continental Shelf Relating to the Island of Senkaku/Diaoyu Between Japan and China Based on the United Nations Convention on the Law of the Sea 1982. Jurnal Komunikasi Hukum (JKH), 3(2), 1-17. https://doi.org/10.23887/JKH.V3I2.11819

Jazuli, A. (2016). Pembangunan Pertahanan dan Keamanan Demi Penegakan Hukum di Indonesia: Kewibawaan Suatu Negara (Development of defence and security for law enforcement In indonesia: a state authority). Jurnal Penelitian Hukum De Jure, 16(2), 187-199. https://doi.org/10.30641/DEJURE.2016.V16.187-199

Kusumaningrum, A. (2017). The Challenges of International Air Law Principles in Globalization Era. Brawijaya Law Journal, 4(2), 255-268. https://doi.org/10.21776/UB.BLJ.2017.004.02.07

Lestari, E. P. (2015). Rekonsepsi Hak Penguasaan Negara atas Wilayah Udara di Tengah Kebijakan Liberalisasi Penerbangan. Jurnal Rechts Vinding: Media Pembinaan Hukum Nasional, 4(2), 327-343. https://doi.org/10.33331/RECHTSVINDING.V4I2.27

Lestari, M. M. (2017). Study of the Right of Foreign Ship Against State Sovereignty (Case Study Indonesia). Indonesian Journal of International Law, 14(4), 497-513. https://doi.org/10.17304/ijil.vol14.4.703

Lestari, M. M. (2021). What is the Right, Archipelagic Sea Lanes and Passage? (According to UNCLOS 1982 and Practice). Indonesian Journal of International Law, 18(2), 209-228. https://doi.org/10.17304/IJIL.VOL18.2.809

Marsono, M., \& D.A.R., D. (2018). Penetapan Air Defence Identification Zone (ADIZ) dalam Rangka Mendukung Kedaulatan Wilayah Udara Nasional. Jurnal Pertahanan \& Bela Negara, 8(2), 1-20. https://doi.org/10.33172/JPBH.V8I2.394

Moon, A. (1963). A Look at Airspace Sovereignty. Journal of Air Law and Commerce, 29(4), 328-345. https://scholar.smu.edu/jalc/vol29/iss4/4

Papp, Z. (2015). Air Defense Identification Zone (ADIZ) in the Light of Public International Law. Pécs Journal of International and European Law, 2015(2), 28- 
54. http://ceere.eu/pjiel/wp-content/uploads/2015/12/pjiel_3_3.pdf

Prabandari, A. P. (2019). Indonesia's Air Sovereignty Issues in the Global Era. Diponegoro Law Review, 4(2), 181-193. https://doi.org/10.14710/DILREV.4.2.2019.181-193

Purwanto, H., \& Mangku, D. G. S. (2016). Legal Instruments of the Republic of Indonesia in Border Management Using the Perspective of Archipelagic State. International Journal of Business, Economics and Law, 11(4), 51-59. https://www.ijbel.com/wp-content/uploads/2017/01/LAW-112.pdf

Rachmawati, I., \& Dewi, M. A. (2020). A Note for Indonesia's Border Diplomacy in Tanjung Datu, West Kalimantan. Jurnal Hubungan Internasional, 9(1), 1-14. https://doi.org/10.18196/HI.91158

Risdiarto, D. (2016). Penegakan Hukum Terhadap Pelanggaran Wilayah Udara Yurisdiksi Indonesia oleh Pesawat Terbang Asing Tidak Terjadwal. Jurnal Rechts Vinding: Media Pembinaan Hukum Nasional, 5(1), 69-82. https://doi.org/10.33331/RECHTSVINDING.V5I1.5

Sa'diyah, N. K., \& Vinata, R. T. (2016). Rekonstruksi Pembentukan National Cyber Defense sebagai Upaya Mempertahankan Kedaulatan Negara. Perspektif, 21(3), 168-187. https://doi.org/10.30742/PERSPEKTIF.V21I3.587

Sefriani, S. (2015). Pelanggaran Ruang Udara oleh Pesawat Asing Menurut Hukum Internasional dan Hukum Nasional Indonesia. Jurnal Hukum IUS QUIA IUSTUM, 22(4), 538-565. https://doi.org/10.20885/IUSTUM.VOL22.ISS4.ART2

Setiani, B. (2018). Konsep Kedaulatan Negara di Ruang Udara dan Upaya Penegakan Pelanggaran Kedaulatan oleh Pesawat Udara Asing. Jurnal Konstitusi, 14(3), 489-510. https://doi.org/10.31078/JK1432

Shaw, M. N. (2003). International Law. Cambridge University Press. https://doi.org/10.1017/CB09781139051903

Silmiwati, S. (2017). Penegakan Hukum Terhadap Zona Larangan Terbang bagi Pesawat Sipil Asing di Indonesia. University Of Bengkulu Law Journal, 2(2), 123134. https://doi.org/10.33369/UBELAJ.2.2.123-134

Sudradjat, R., \& Wahyuningsih, S. E. (2020). Jurisdiction Problems For The Indonesian National Aerospace. International Journal of Innovative Research and Advanced Studies (IJIRAS), 7(6), 12-19. https://www.ijiras.com/2020/Vol_7Issue_6/paper_2.pdf

Yustitianingtyas, L., Babussalam, B., \& Wijayanti, A. (2021). Pengendalian Keselamatan Penerbangan sebagai Upaya Penegakan Kedaulatan Negara di Ruang Udara dan Implikasinya di Indonesia. Jurnal Komunikasi Hukum (JKH), 7(1), 252-265. https://doi.org/10.23887/JKH.V7I1.31474 